\title{
Telmisartan inhibits the progression of cardiomyopathy in daunorubicin treated rats: the role of advanced glycation end products
}

\author{
Wawaimuli Arozal, ${ }^{1,2}$ Kenichi Watanabe, ${ }^{2}$ Punniyakoti T. Veeraveedu, ${ }^{2}$ Meilei Ma,${ }^{2}$ Nafrialdi ${ }^{1}$ \\ ${ }^{1}$ Department of Pharmacology, Faculty of Medicine, Universitas Indonesia, Jakarta, Indonesia \\ ${ }^{2}$ Department of Clinical Pharmacology, Faculty of Pharmaceutical Sciences, Niigata University of Pharmacy and \\ Applied Life Sciences, Niigata City, Japan
}

\begin{abstract}
Abstrak
Latar belakang: Antrasiklin diketahui dapat menimbulkan toksisitas pada jantung melalui mekanisme peningkatan pembentukan advanced glycation end-products (AGEs), yakni pentosidine dan Ne-(carboxylmethyl)lysine (CML). Penelitian ini bertujuan mengetahui efek telmisartan (TLM) suatu antagonis reseptor angiotensin II (ARB) terhadap toksisitas jantung yang diinduksi oleh antrasiklin.

Metode: Tikus galur Sprague Dawley dibagi secara acak menjadi 3 kelompok: kelompok pertama mendapat daunorubisin (DNR) $3 \mathrm{mg} / \mathrm{kgBB}$ dua hari sekali hingga mencapai dosis kumulatif $9 \mathrm{mg} / \mathrm{kgBB}$. Kelompok kedua mendapat DNR ditambah $T L M 10 \mathrm{mg} / \mathrm{kgBB} / \mathrm{hari}$, secara oral selama 6 minggu, sedangkan kelompok kontrol (CTL) hanya mendapat pelarut DNR. Rerata tekanan darah (MBP), tekanan ventrikel kiri (LVP), tekanan diastolik akhir ventrikel kiri (LVEDP), dan kontraktilitas ventrikel ( $\pm d P / d t)$ diukur dengan menggunakan Powerlab. Sedangkan fraksi ejeksi (EF) dan fraksi pemendekan (FS) dinilai dengan ekokardiografi. Ekspresi reseptor AGE (RAGE), pentosidin, dan CML diperiksa dengan imunohistokimia dan western blot.

Hasil: DNR menyebabkan perburukan beberapa parameter hemodinamik yang dapat diperbaiki oleh TLM, yakni : LVP : 124,3 $\pm 6,0 ; 111 \pm 7$; dan 115,1 $\pm 5,4 \mathrm{mmHg}$, untuk kelompok CTL, DNR, dan DNR-TLM. LVEDP: 7,5 \pm 0,9; $10,7 \pm 0,3 ; 8,7 \pm 0,4 \mathrm{mmHg}$, dan; $+d P / d t: 6813 \pm 541 ; 4800 \pm 345 ; 5950 \pm 398 \mathrm{mmHg} / \mathrm{s}$. Hal yang sama juga terlihat pada parameter ekokardiografi, yakni: EF: 78,9 $\pm 1,8 ; 59.6 \pm 1,4 ; 76,2 \pm 2,75 \% ; F S: 42,8 \pm 1,7 ; 29,1 \pm 1,3 ; 41 \pm$ 2,7\% untuk kelompok CTL, DNR and DNR-TLM. Ekspresi protein RAGE, pentosidine dan CML meningkat pada pemberian DNR yang kemudian dihambat dengan pemberian bersama TLM.
\end{abstract}

Kesimpulan: AGE berperan pada toksisitas jantung akibat pemberian DNR. Telmisartan dapat menghambat efek tersebut dengan menurunkan ekspresi RAGE. (Med J Indones 2011; 20:255-62)

\begin{abstract}
Background: Anthracyclines have been reported to induce cardiotoxicity through mechanisms involving formation of advanced glycation end-products (AGEs), including pentosidine and $\mathrm{N} \epsilon$-(carboxymethyl) lysine (CML). We investigated the potential utility of telmisartan (TML), an angiotensin II receptor antagonists (ARB) on anthracycline-induced cardiotoxicity.
\end{abstract}

Methods: Three groups of Sprague-Dawley rats were treated as follows: The first group received daunorubicin (DNR) $3 \mathrm{mg} / \mathrm{kgBW}$ every alternating day to reach a cumulative dose of $9 \mathrm{mg} / \mathrm{kg}$ DNR. The second group received DNR plus TLM at a dose $10 \mathrm{mg} / \mathrm{kgBW}$, by oral gavage for 6 weeks, and the third group served as control group (CTL) which only received vehicle of DNR. Mean blood pressure (MBP) peak left ventricular pressure (LVP), LV end-diastolic pressure (LVEDP), and intra-ventricular contractility $( \pm \mathrm{dP} / \mathrm{dt})$ were recorded by using Powerlab instrumentation. Ejection fraction (EF), and fractional shortening (FS) were measured by echocardiography. Expression of receptor of AGE (RAGE), pentosidine and CML were measured by immunohistochemistry and Western blot in LV tissue.

Results: DNR treatment was associated with significant weakening of some hemodynamic parameters which could be reversed by TML (LVP: $124.3 \pm 6.0 ; 111 \pm 7$; and $115.1 \pm 5.4 \mathrm{mmHg}$, respectively in CTL, DNR and DNR-TLM groups; LVEDP: $7.5 \pm 0.9 ; 10.7 \pm 0.3 ; 8.7 \pm 0.4 \mathrm{mmHg}$, respectively; $+\mathrm{dP} / \mathrm{dt}: 6813 \pm 541 ; 4800 \pm 345 ; 5950 \pm 398$ $\mathrm{mmHg} / \mathrm{s}$, respectively). The same phenomenons were also observed on echocardiographic parameters (EF: $78.9 \pm 1.8$; $59.6 \pm 1.4 ; 76.2 \pm 2.75 \%$, resepectively; FS: $42.8 \pm 1.7 ; 29.1 \pm 1.3 ; 41 \pm 2.7 \%$ ) respectively. Expression of RAGE as well as pentosidine and CML were increased in DNR-rats. TML treatment ameliorated these changes.

Conclusion: These results suggested the role of AGE formation in DNR-induced cardiotoxicity and telmisartan could inhibit the progression of cardiac toxicity at least in part by reduction RAGE expressiom. (Med J Indones 2011; 20:255-62)

Keywords: advanced glycation end product, anthracyline, cardiotoxicity, daunorubicin, telmisartan 
Daunorubicin (DNR), one of anthracycline antibiotics are potent antineoplastic agents. Unfortunately, despite its broad effectiveness, the clinical use of DNR is limited by a dose dependent and cumulative cardiotoxicity. ${ }^{1}$ The adverse effect can vary from transient electrocardiography abnormalities to cardiomyopathy and heart failure. ${ }^{2}$ Among the proposed mechanisms by which anthracyline cause irreversible myocardial injury, free radical formation is generally accepted as the main mechanism. ${ }^{3}$ Cardiomyocytes have poor antioxidant defense systems, and free oxygen radicals can damage various targets in these cells.

Non-enzymatic modification of proteins by a formation of reduced-sugar leads to the formation of advanced glycation end products (AGEs), whose process has been reported to progress under physiological aging, oxidative stress or diabetic conditions. There have been only a few reports outlining the contribution of AGE formation to the adverse effects of medicinal drugs. ${ }^{4}$ Very recently, Moriyama et $\mathrm{al}^{5}$ reported that doxorubicin (DOX), another anthracycline, accelerated the formation of pentosidine and $\mathrm{N}$-(carboxylmethyl) lysine (CML), both of them are well known AGEs, in the heart through enhanced oxidative stress and its suggests that AGE formation is involved in DOXinduced cardiomyopathy.

Telmisartan is a selective angiotensin II (Ang II) type I receptor (AT1R) blocker (ARB) that is used in the hypertension treatment, and it exerts a variety of pleiotropic effects, including anti-oxidative, antiapoptotic, and anti-inflammatory effects. Furthermore, telmisartan could confer effects other than the blockage of the AT1R, such as peroxisome proliferator-activated receptor (PPAR) $\gamma$ activation ${ }^{6}$ and there were evidences reported that telmisartan could down-regulate RAGE expression and suppress its downstream signaling in various cells through its unique PPAR- $\gamma$ modulating activity. ${ }^{7}$ Previously, we have reported the effect of telmisartan in limiting the cardiotoxic effect of DNR by inhibiting the action of Ang II via AT-1R, which reverses oxidative stress and myocardial apoptosis, ${ }^{8}$ but this study was conducted for only 12 days, as acute model and did not investigate the involvement of AGEs and RAGE in DNR-induced cardiomyopathy.

Based on those above reports, it is of interest to check whether there is an involvement of AGEs and its receptor RAGE in DNR-induced cardiomyopathy in rats. In addition it was known that $\mathrm{ARB}$ and angiotensinconverting enzyme (ACE) inhibitor inhibit the formation of two AGEs, pentosidine and $\mathrm{CML}^{9}$ and the expression of its receptor RAGE ${ }^{10}$ in vitro, indicating a cross-talk exists between the AGE-RAGE system and the renin angiotensin system (RAS). Taking all the above facts together, we examined here whether AGE and RAGE involves in DNR-induced cardiomyopathy and verify the efficacy of 6 weeks of treatment with telmisartan.. We posited that telmisartan may inhibit the formation of AGE, expression of RAGE in association with attenuation of myocardial damage induced by DNR.

\section{METHODS}

This study was done between July to September 2010 Department Clinical Pharmacology Niigata University of pharmacy and applied life science and data analysis was performed at the Department of Pharmacology and Therapeutics. Faculty of Medicine, Universitas Indonesia.

\section{Drugs and chemicals}

Unless otherwise stated all reagents were of analytical grade and purchased from Sigma (Tokyo, Japan). DNR was kindly donated by Meiji Seika Kaisha Ltd., Tokyo, Japan. Telmisartan was donated by Boehringer Ingelheim $\mathrm{GmbH}$ (Ingelheim am Rhein, Germany).

\section{Animals and treatment}

Eight-week-old male Sprague-Dawley rats were obtained from Charles River Japan Inc. (Kanagawa, Japan). The animals were quarantined and acclimatized for 2 weeks prior to the initiation of the experiments. On day 0 , each animal received a single intravenous injection of DNR at a dose of $3 \mathrm{mg} / \mathrm{kg}$ (i.v.). The drug was administered in three equal injections at $48 \mathrm{~h}$ intervals for a period of one week to achieve an accumulative dose of $9 \mathrm{mg} / \mathrm{kg}$, which is well documented to produce cardiotoxicity. ${ }^{11,12}$ Age-matched rats were injected with corresponding volumes of $0.9 \% \mathrm{NaCl}$ and used as a control (group CTL; $n=5$ ). Twenty-two DNRtreated rats were randomly divided into two groups and received oral administration of telmisartan $(10 \mathrm{mg} /$ $\mathrm{kg}$ /day; group DNR+TLM; $\mathrm{n}=10$ ) or vehicle (group DNR; $n=12$ ). The dose of telmisartan was chosen on the basis of the previous reports..$^{13}$ Administration of telmisartan was started on the same day as DNR administration and continued for 5 additional weeks after cessation of DNR administration (6 weeks total period). This duration of study was chosen on the basis of the previous reports. ${ }^{11,14,15}$ The animal experiments were performed in accordance with national guidelines for the use and care of laboratory animals and were approved by the local animal committee of Niigata University of Pharmacy and Applied Life Sciences.

\section{Hemodynamic and echocardiographic study}

After the end of the study period (6 weeks), rats were anesthetized with $2 \%$ halothane in $\mathrm{O}_{2}$ and subjected 
to surgical procedures to measure hemodynamic parameters. After the instrumentation, the concentration of halothane was reduced to $0.5 \%$ to record steady-state hemodynamic data. Hemodynamic parameters such as mean blood pressure (MBP), peak left ventricular pressure (LVP), LV end-diastolic pressure (LVEDP), and the rate of intra-ventricular pressure rise and decline $( \pm \mathrm{dP} / \mathrm{dt})$ were recorded as previously described. ${ }^{16}$

Two-dimensional echocardiographic studies were performed under $0.5 \%$ halothane anesthesia using an echocardiographic machine equipped with a $7.5-\mathrm{MHz}$ transducer (SSD-5500; Aloka, Tokyo, Japan). M-mode tracings were recorded from the epicardial surface of the right ventricle; the short axis view of the left ventricle was recorded to measure the LV dimension in diastole (LVDd) and LV dimension in systole (LVDs). LV fractional shortening (FS) and ejection fraction (EF) were calculated and expressed as percentages. The study was performed in a blinded manner.

\section{Histopathological analysis}

After the measurement of echocardiographic parameters, hearts were excised and weighed immediately (HW), and its ratio to BW (HW/BW) was calculated. Half of heart was immediately snap-frozen in liquid nitrogen for subsequent protein extraction and enzymatic assays. The remaining excised hearts were cut into about 2-mm-thick transverse slices and fixed in $10 \%$ formalin. After being embedded in paraffin, several transverse sections were obtained from the heart and stained with hematoxylin and eosin (H\&E) for histological evaluation, and also stained with AzanMallory to demonstrate fibrosis in heart tissues. The frequency and the severity of lesions in the hearts were assessed semi-quantitatively as previously reported ${ }^{13,17}$ by light microscopy using a scale where score 0 , normal; 1 , mild; 2, moderate; and 3, severe. The scoring criteria for myocardial lesions included the degree of myocyte vacuolization with respect to size and the number of vacuoles, degree of fibrosis, myocardial degeneration and interstitial edema and loss of myofibrils.

\section{Immunohistochemistry for pentosidine and RAGE}

Formalin-fixed, paraffin-embedded heart tissue sections were used for immunohistochemical staining. After deparaffinization and hydration, the slides were washed in Tris-buffered saline (TBS; $10 \mathrm{mM} / 1$ Tris $\mathrm{HCl}, 0.85 \%$ $\mathrm{NaCl}, \mathrm{pH}$ 7.2). Endogenous peroxidase activity was quenched by incubating the slides in methanol and $0.3 \%$ $\mathrm{H}_{2} \mathrm{O}_{2}$ in methanol. After overnight incubation with the primary antibody, anti-pentosidine monoclonal antibody (PEN-12, Transgenic Inc. Kumamoto, Japan), or antiRAGE polyclonal antibody (Santa Cruz Biotechnology Inc., CA, USA) diluted 1:50, at $4^{\circ} \mathrm{C}$, the slides were washed in TBS and then horseradish peroxidase (HRP)conjugated secondary antibody was added and the slides were further incubated at room temperature for $45 \mathrm{~min}$. The slides were washed in TBS and incubated with diaminobenzidine tetrahydrochloride as the substrate, and counterstained with hematoxylin. A negative control without primary antibody was included in the experiment to verify the antibody specificity.

\section{Protein analysis by Western blotting}

Protein lysate was prepared from heart tissue as described previously. ${ }^{18}$ The total protein concentration in samples was measured by the bicinchoninic acid method. ${ }^{19}$ For the determination of protein levels of CML and RAGE, equal amounts of protein extracts $(30 \mu \mathrm{g})$ were separated by sodium dodecyl sulfate (SDS) polyacrylamide gel electrophoresis (Bio-Rad, CA, U.S.A) and transferred electrophoretically to nitrocellulose membranes. Membranes were blocked with 5\% non-fat dry milk in Tris-buffered saline Tween (20 mM Tris, $\mathrm{pH} 7.6,137 \mathrm{mM} \mathrm{NaCl}$, and $0.1 \%$ Tween 20). All antibodies were purchased from Santa Cruz Biotechnology Inc., CA, USA aside from NF-кB p65 (Cell Signaling Technology Inc., Beverly, MA, USA), and CML (Abcam Inc., Cambridge, UK) and used at a dilution of 1:1000. The membrane was incubated overnight at $4^{\circ} \mathrm{C}$ with the primary antibody, and the bound antibody was visualized using the respective HRP-conjugated secondary antibodies (Santa Cruz Biotechnology Inc.) and chemiluminescence developing agents (GE Healthcare, Buckinghamshire, UK). The level of glyceraldehyde 3-phosphate dehydrogenase (GAPDH) was estimated in every sample to check for equal loading of samples. Films were scanned and band densities were quantified with densitometric analysis using Scion Image program(Epson GT-X700, Tokyo, Japan). Finally, Western blot data were normalized by those for heart GAPDH.

\section{Statistical analysis}

Data are presented as mean \pm S.E.M and were analyzed using one-way analysis of variance followed by Tukey or Bonferroni methods for post-hoc analysis and two-tailed t-test when appropriate. A value of $p<0.05$ was considered statistically significant. For statistical analysis GraphPad Prism 5 software (San Diego, CA, USA) was used.

\section{RESULTS}

Six of 12 rats in DNR group died between days 14 and 42 (Table 1). None of the rats died in group Control and DNR-TLM.

\section{Effect of telmisartan on myocardial functions}

LVEDP was significantly higher $(10.7 \pm 0.3$ vs $7.5 \pm 0.9$ $\mathrm{mmHg}, p<0.05)$ and LVP and $\pm \mathrm{dP} / \mathrm{dt}$ were significantly 
lower in group DNR than in group Control $(111 \pm 7$ vs 124.3 $\mathrm{mmHg}, p<0.05$; and $4800 \pm 345$ vs $6813 \pm 541 \mathrm{mmHg} / \mathrm{s}$, $p<0.05 ; 4135 \pm 365$ vs $7290 \pm 775 \mathrm{mmHg} / \mathrm{s}, \quad p<0.05$, respectively), indicating systolic and diastolic dysfunction in DNR rats. Telmisartan treatment improved the myocardial dysfunction by significant reduction in LVEDP $(8.7 \pm 0.4$ vs $10.7 \pm 0.3 \mathrm{mmHg}, p<0.05)$ and elevation in the $\pm \mathrm{dP} / \mathrm{dt}(5950 \pm 398$ vs $4800 \pm 345 \mathrm{mmHg} / \mathrm{s}$ and $6079 \pm 739$ vs $4135 \pm 365 \mathrm{mmHg} / \mathrm{s}, p<0.05$, respectively) compared with those in group DNR (Table 1).

Echocardiographic data revealed that LV systolic function, as assessed by $\mathrm{FS}$ and $\mathrm{EF}$ was reduced significantly in group DNR compared with that in group Control $(29.1 \pm 1.3$ vs $42.8 \pm 1.7 \%, p<0.05$; and $59.6 \pm 1.4$ vs $78.9 \pm 1.8 \%, p<0.05$, respectively). The reductions in both FS and EF were significantly attenuated in group DNR+Telm $(41 \pm 2.7$ vs $29.1 \pm 1.3 \%, p<0.05$; and $76.2 \pm 2.7$ vs $59.6 \pm 1.4 \%$, $p<0.05$, respectively) (Table 1 ).

\section{Effect of telmisartan on cardiac histopathology}

Histological changes in heart were evaluated as described in the methods and the results are presented in Table 2 and Fig. 1A and B. In the heart tissues, normal histological findings were seen in the control group. On the other hand, there were histological changes in the DNR group. Qualitatively, DNR-induced cardiac damage was recognized by the presence of marked interstitial edema, myocardial fibrosis, perinuclear vacuolization, and degeneration of the myocardium. The lesions were significantly reduced in the group treated with telmisartan compared with those in the DNR group (Table 2 and Fig. 1A, B).

Table 1. Changes in survival rate, histopathological, hemodynamic, and echocardiographic parameters after 6 weeks of treatment with telmisartan in DNR rats

\begin{tabular}{|c|c|c|c|}
\hline & Control & DNR & $\mathrm{DNR}+\mathrm{Telm}$ \\
\hline & $\mathrm{n}=5$ & $\mathrm{n}=12$ & $\mathrm{n}=10$ \\
\hline Survival rate $(\%)$ & 100 & 50 & 100 \\
\hline Body Weight (g) & $540 \pm 8.9$ & $379 \pm 9^{*}$ & $380.5 \pm 8.4^{*}$ \\
\hline Heart Weight (g) & $1.23 \pm 0.02$ & $1.09 \pm 0.01^{*}$ & $0.95 \pm 0.03$ \\
\hline HW/BW ratio $(\mathrm{g} / \mathrm{kg})$ & $2.3 \pm 0.02$ & $2.9 \pm 0.06^{*}$ & $2.52 \pm 0.09$ \\
\hline \multicolumn{4}{|c|}{ Hemodynamic and Echocardiographic data } \\
\hline $\mathrm{CVP}(\mathrm{mmHg})$ & $-0.45 \pm 0.4$ & $0.42 \pm 0.05$ & $-0.26 \pm 0.36$ \\
\hline MBP (mmHg) & $95 \pm 7.6$ & $85 \pm 5.6$ & $85.93+5.56$ \\
\hline LVP (mmHg) & $12 \overline{4} .3 \pm 6$ & $11 \overline{1} \pm 7^{*}$ & $115.1 \pm 5.4$ \\
\hline LVEDP (mmHg) & $7.5 \pm 0.9$ & $10.7 \pm 0.3^{*}$ & $8.7 \pm 0.4^{\#}$ \\
\hline$+\mathrm{dP} / \mathrm{dt}(\mathrm{mmHg} / \mathrm{s})$ & $6813 \pm 541$ & $4800 \pm 345^{*}$ & $5950 \pm 398^{\#}$ \\
\hline$-\mathrm{dP} / \mathrm{dt}(\mathrm{mmHg} / \mathrm{s})$ & $7290 \pm 775$ & $4135 \pm 365^{*}$ & $6079 \pm 739^{\#}$ \\
\hline HR (beats/min) & $336 \pm 38$ & $334 \pm 11$ & $359.2 \pm 20.9$ \\
\hline LVDd (mm) & $6.6 \pm 0.5$ & $7.5 \pm 0.3^{*}$ & $7 \pm 0.2$ \\
\hline LVDs (mm) & $4.4 \pm 0.3$ & $5.3 \pm 0.2^{*}$ & $4 . \overline{1} \pm 0.3^{\#}$ \\
\hline FS $(\%)$ & $42.8 \pm 1.7$ & $29.1 \pm 1.3^{*}$ & $41 \pm 2.7^{\#}$ \\
\hline EF (\%) & $78.9+1.8$ & $59.6 \pm 1.4^{*}$ & $76.2 \pm 2.7^{\#}$ \\
\hline
\end{tabular}

Results are presented as the mean \pm SEM. HW/BW, ratio of heart weight to body weight; CVP, central venous pressure; MBP, mean blood pressure; LVP, left ventricular pressure; LVEDP, left ventricular end-diastolic pressure; $\pm \mathrm{dP} / \mathrm{dt}$, rate of intra-ventricular pressure rise and decline; HR, heart rate; LVDd, left ventricular dimension in diastole; LVDs, left ventricular dimension in systole; FS, fractional shortening; EF, ejection fraction; group N, aged matched normal rats; group DNR, DNR rats treated with vehicle; group DNR+Telm, DNR rats treated with telmisartan $(10 \mathrm{mg} / \mathrm{kg} / \mathrm{day})$.

$* \mathrm{P}<0.05$ vs. group control and $\# \mathrm{P}<0.05$ vs. group $\mathrm{DNR}$

Table 2. Effect of telmisartan on histopatological changes in cardiac tissues after 6 weeks of treatment in DNR rats

\begin{tabular}{|c|c|c|c|}
\hline \multirow{2}{*}{$\begin{array}{l}\text { Histopathological } \\
\text { finding }\end{array}$} & Control & DNR & DNR+Telm \\
\hline & $\mathrm{n}=5$ & $\mathrm{n}=6$ & $\mathrm{n}=10$ \\
\hline Myocardial fibrosis & $0.0 \pm 0.0$ & $1.4 \pm 0.24^{*}$ & $0.6 \pm 0.24^{\#}$ \\
\hline Perinuclear vacuolization & $0.0 \pm 0.0$ & $0.6 \pm 0.24^{*}$ & $0.4 \pm 0.24^{\#}$ \\
\hline Myocardial degeneration & $0.0 \pm 0.0$ & $2.6 \pm 0.24^{*}$ & $1.2 \pm 0.2^{\#}$ \\
\hline Interstitial edema & $0.0 \pm 0.0$ & $2.6 \pm 0.24^{*}$ & $1.4 \pm 0.24^{\#}$ \\
\hline
\end{tabular}

Results are presented as the mean \pm SEM. group $\mathrm{N}$, aged matched normal rats; group DNR, DNR rats treated with vehicle; group DNR+Telm, DNR rats treated with telmisar$\tan (10 \mathrm{mg} / \mathrm{kg} / \mathrm{day}) .{ }^{*} \mathrm{p}<0.05$ vs. group control and $\# \mathrm{p}<0.05$ vs. group DNR 


\section{Effect of telmisartan on myocardial level of pentosidine, and RAGE}

Myocardial immunoreactiviy as assessed by immunohistochemistry for pentosidine, and RAGE were increased in the group DNR compared with those of group Control, which were attenuated with telmisartan cotreatment (Fig. 2A and B).

\section{Effect of telmisartan on myocardial protein expressions of CML and RAGE}

Myocardial protein expression of CML and RAGE as assessed by western blotting was decreased in group DNR compared with that in group Control, and telmisartan treatment significantly attenuated the decrease in protein expressions of CML and RAGE (Fig. 3A and B).
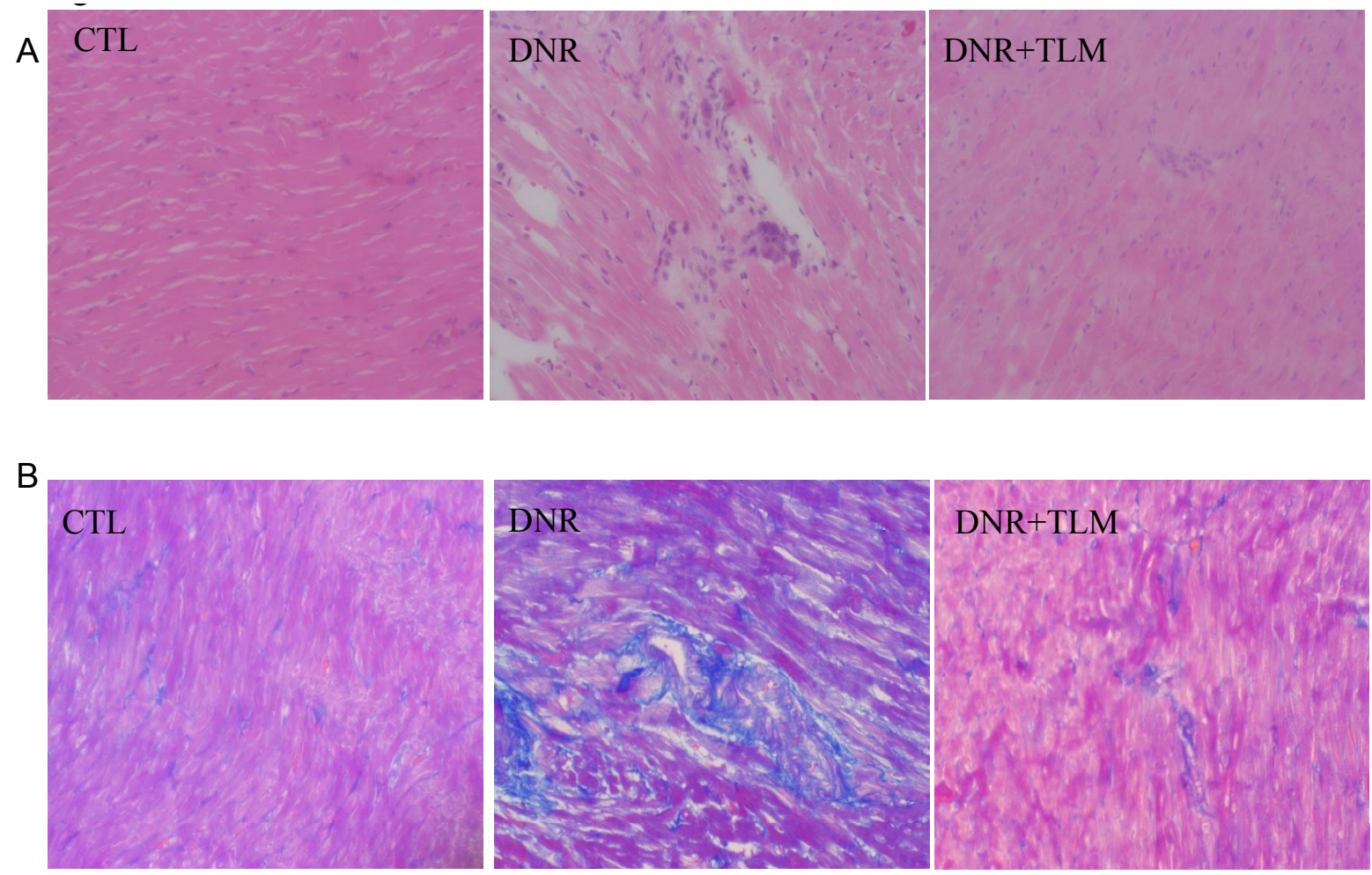

Figure 1. A. Hematoxylin and eosin staining of the cross-sectional tissue slices of hearts depicting interstitial edema, vacuolization and degeneration of cardiac fibers (X200). B, Azan-Mallory staining for fibrosis of the cross-sectional tissue slices of hearts. Fibrosis is indicated by the blue area as opposed to the red myocardium (X200).

A

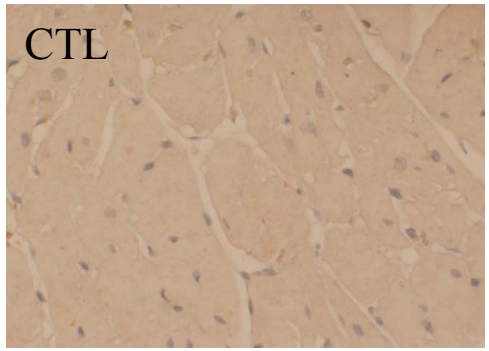

B

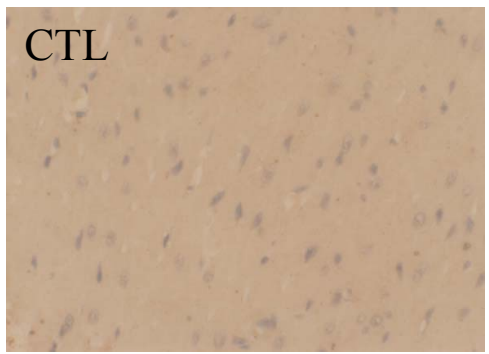

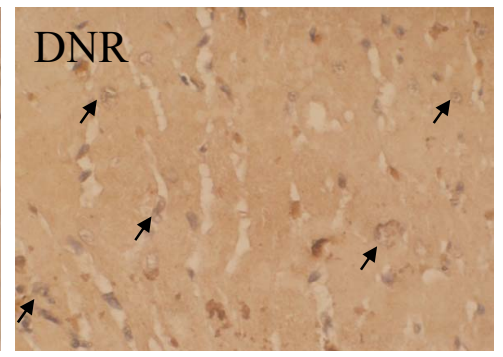

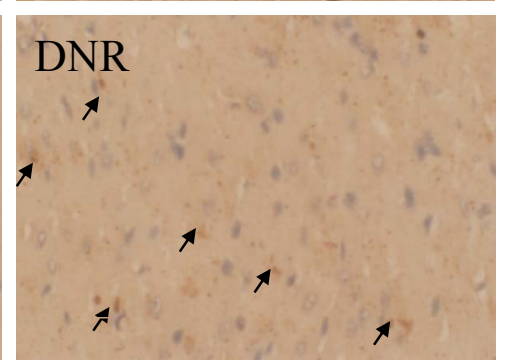

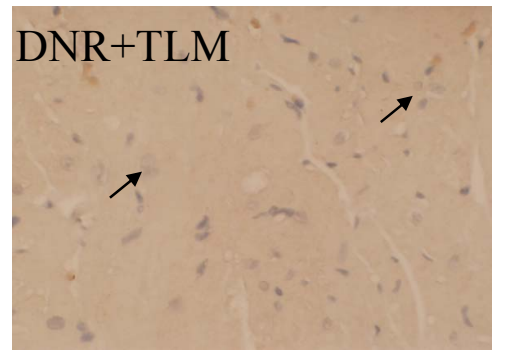

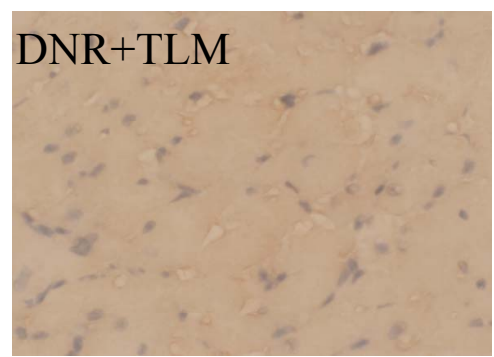

Figure 2. Immunohistochemical staining for pentosidine (A) and RAGE (B) in LV section (X400). Antibodies were detected by diaminobenzidine method that produces a brown color (arrow). Group CTL, age-matched normal rats; group DNR, DNR-treated rats administered with vehicle; group DNR+TLM, DNR-treated rats administered with telmisartan $(10 \mathrm{mg} / \mathrm{kg} /$ day $)$. 

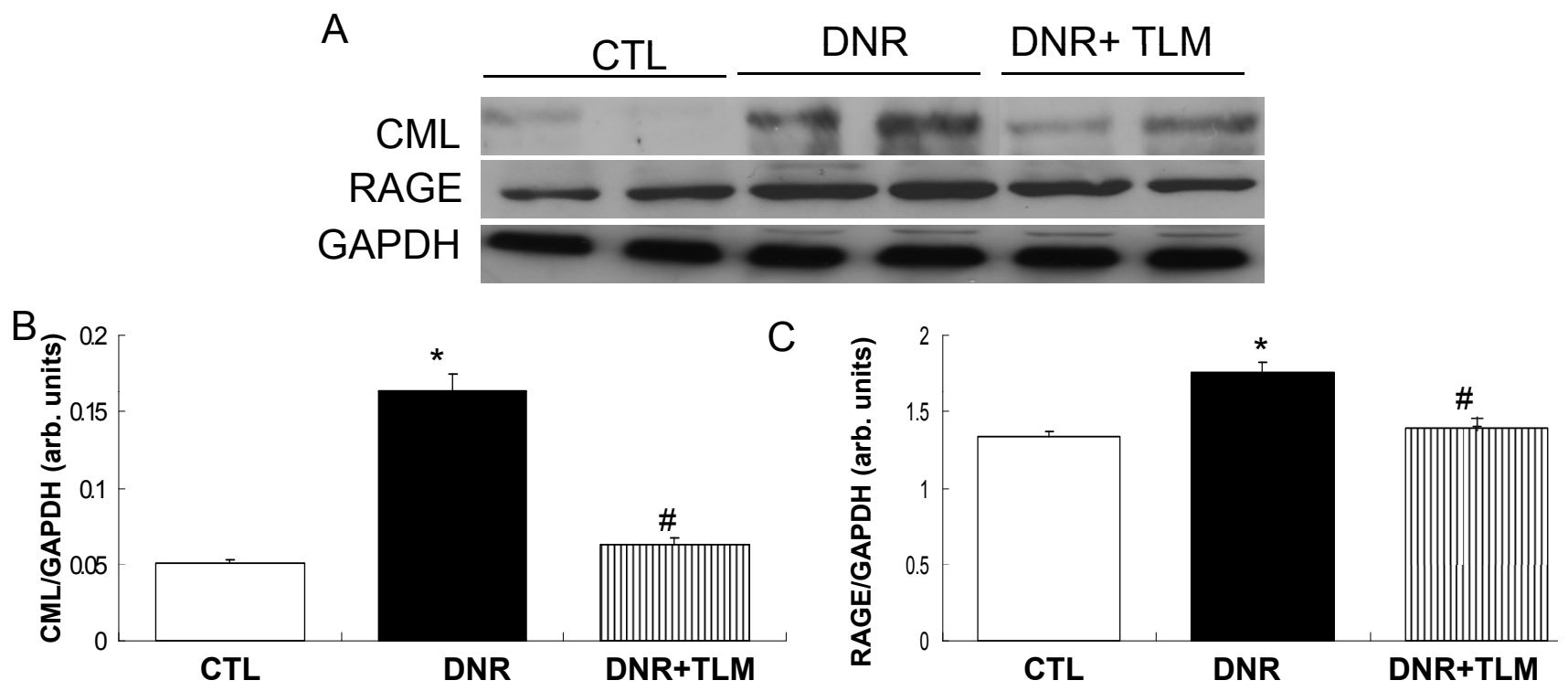

Figure 3. Myocardial expressions of CML and RAGE. A, Representative western blots showing specific bands for CML, RAGE and GAPDH as an internal control. Equal amounts of protein sample $(30 \mu \mathrm{g})$ obtained from whole ventricular homogenate were applied in each lane. These bands are representative of five separate experiments. B-C, Densitometric data of protein analysis. The mean density values of CML and RAGE were expressed as ratios relative to that of GAPDH. Each bar represents mean $\mu$ S.E.M. Group CTL, age-matched normal rats; group DNR, DNR-treated rats administered with vehicle; group DNR+TLM, DNR-treated rats administered with telmisartan $\left(30 \mathrm{mg} / \mathrm{kg} /\right.$ day). ${ }^{*} p<0.05$ vs. group Control; $\# p<0.05$ vs. group DNR.

\section{DISCUSSION}

Although anthracycline-induced free radicals are believed to play a central role in its cardiotoxicity, ${ }^{1}$ the precise mechanism of myocardial impairment remains unclear. It is hoped that an enhanced understanding of the mechanisms underlying DNR-induced cardiomyopathy will enable the development of novel therapies that may prevent and treat the heart failure. In the present study, we confirmed-to our knowledge, for the first time- the contribution of AGE formation in DNR-induced cardiomyopathy in rats and that addition of telmisartan, a unique ARB with PPAR- $\gamma$ modulating activity during treatment with DNR reduced its cardiac damage in vivo.

In this study, DNR-induced cardiomyopathy was characterized by a deterioration of cardiac function as indicated by the deterioration in hemodynamic (LVP, LVDP, and $\mathrm{dP} / \mathrm{dt}$ ) and echocardiographic parameters (FS and EF) and confirmed by a severe histopathological features in the heart (Fig 1A and $\mathrm{B}$ and Table 1 and 2) which was in agreement with previous reports. ${ }^{11,13}$ Concomitantly, in the present study involvement of AGE formation was confirmed by increased myocardial protein expression of CML and myocardial immunostaining of pentosidine in DNRrats (Figs. 2A and 5A, B). Very recently, Moriyama et al. ${ }^{5}$ reported that DOX accelerates the formation of pentosidine and CML in the heart through enhanced oxidative stress and that AGE formation is involved in DOX-induced cardiomyopathy. The formation of pentosidine and CML is thought to be closely linked, not only to glycation, but also to oxidative stress. ${ }^{20}$ In addition, the final step of the Maillard reaction is driven by oxidative stress. ${ }^{21}$ Since the contribution of oxidative stress on anthracyclines-induced cardiotoxicity has been reported by some investigators $(22,23)$, the results of the present study suggest that AGE formation is involved in the DNR-induced cardiomyopathy and the enhanced AGE formation by DNR in this present study might be associated with the enhanced oxidative and nitrosative stress to the cardiomyocyte.

In the present study, we found that telmisartan treatment attenuated the increased myocardial protein expression of CML and myocardial immunostaining of pentosidine in DNR-rats. Blockade of AGE formation or accumulation by renin-angiotensin system (RAS) inhibitors was reported both in vitro and in vivo.9,24 Olmesartan has been reported to inhibit the formation of pentosidine and CML by chelating transition metals and inhibits various oxidative steps in vitro. ${ }^{9}$ However, no study reported the crosstalk between RAS and the AGE-RAGE axis in anthracycline-induced cardiomyopathy. Telmisartan has been proven to inhibit intracellular oxidative stress, at least in part, in a receptor-independent manner, possibly owing to its lipophilic and anti-oxidant structure. ${ }^{27}$ In type I diabetic patients, telmisartan succeeded to improve endothelial function and decrease the nitrotyrosine plasma levels. ${ }^{28}$ 
Thus, the mechanisms underlying the cardioprotective effects of telmisartan in our model may, in part, be due to the reduction in the formation of pentosidine and CML and oxidative stress.

Recent studies have shown that AGEs and their receptor (RAGE) axis is implicated in the pathogenesis of various devastating disorders such as diabetic, cardiovascular disease, and cancer growth and metastasis, ${ }^{21}$ but only a few reports outlining the contribution of AGE formation and RAGE to the adverse effects of medicinal drugs. ${ }^{4}$ Therefore, we further examined whether DNR could increased RAGE expression in the heart tissue. As shown in Figs. 2B, 4A, and B, RAGE protein expression assessed by Western blotting and immunohistochemical staining in the heart tissue was increased in DNR-rats which was inhibited by cotreatment with telmisartan. The present findings have extended previous observations that other ARBs such as olmesartan and irbesartan inhibited the AGE-signaling to angiogenesis, inflammation and thrombogenesis by reducing the RAGE expression in culturedcells. ${ }^{27-29}$ Therefore, ourpresentstudy results suggest that there could also existence of a pathophysiological crosstalk between the RAS and the AGE-RAGE axis in DNR induced cardiac damage. Blockade of the RAS by telmisartan may play a protective role against cardiac injury in DNR-rats by attenuating the deleterious effects of AGEs via down-regulation of RAGE expression.

In conclusion, the formation of AGEs; pentosidine and CML might accelerates in DNR-induced cardiotoxicity and telmisartan could inhibits the progression of DNRinduced cardiomyopathy probably by alteration of AGEs formation through their receptor, RAGE.

\section{Acknowledgments}

This research was supported by a Yujin Memorial Grant, Ministry of Education, Culture, Sports and Technology of Japan and by a grant from the Promotion and Mutual Aid Corporation for Private Schools, Japan. We thank Flori Ratna Sari, Hiroko Shimazaki, Sayaka Mito, and Yoshiyasu Kobayashi for their assistance in this research work.

\section{REFERENCES}

1. Simunek T, Stirba M, Popelova O, Adamcova M, Hridina R, Gersl, V. Anthracycline-induced cardiotoxicity: overview of studies examining the roles of oxidative stress and free cellular iron. Pharmacol Rep. 2009;61:154-71.

2. Gianni L, Herman EH, Lipshultz SE, Minotti G, Sarvazyan, Sawyer DB.. Anthracyline cardiotoxicity: from bench to bedside. J Clin Oncol. 2008;26: 3777-84.

3. Saad SY, Najjar TA, Arafah MM.. Cardioprotective effects of subcutaneous ebselen against daunorubicin-induced cardiomyopathy in rats. Basic Clin Pharmacol Toxicol. 2006;99: 412-7.
4. Yosihara K, Nagayama Y, Horiguchi H, Yoshida S, Tohyoh S, Takahashi, S., et al. Acceleration of pentosidine formation by medication. Int Congr Ser. 2002;1245: 425-6.

5. Moriyama T, Kemi M, Okumura C, Yoshihara K, Horie T. Involvement of advanced glycation end-products, pentosidine and $\mathrm{N}$ (epsilon)-(carboxymethyl)lysine, in doxorubicininduced cardiomyopathy in rats. Toxicology. 2010;268:89-97.

6. Benson SC, Pershadsingh HA, Ho CI, Chittiboyina A, Desai $\mathrm{P}$, Pravenec $\mathrm{M}$ et al. Identification of telmisartan as a unique angiotensin II receptorantagonist with selective PPARgammamodulating activity. Hypertension. 2004;43:993-1002.

7. Yamagishi S, Nakamura $K$, Matsui T.. Regulation of advanced glycation end product (AGE)-receptor (RAGE) system by PPAR-gamma agonists and its implication in cardiovascular disease. Pharmacol Res. 2009;60:174-8.

8. Arozal W, Watanabe K, Veeraveedu PT, Thandavarayan RA, Harima M, Sukumaran, V et al. Effect of telmisartan in limiting the cardiotoxic effect of daunorubicin in rats. $\mathrm{J}$ Pharm Pharmacol. 2010;62:1776-83.

9. Miyata T, van Ypersele de Strihou C, Ueda Y, Ichimiro K, Inagi R, Onogi $\mathrm{H}$, et al. Angiotensin II receptor blockers and angiotensin converting enzyme inhibitors lower in vitro the formation of advanced glycation end products: biochemical mechanism. J Am Soc Nephrol. 2002;13:2478-87.

10. Nakamura, K., Yamagishi, S., Nakamura, Y., Takenaka, K., Matsui, T., Jinnouchi Y.Telmisartan inhibits expression of a receptor for advanced glycation end products (RAGE) in angiotensin-II-exposed endothelial cells and decreases serum levels of soluble RAGE in patients with essential hypertension. Microvasc Res. 2005;70:137-41.

11. Arozal W, Watanabe K, Veeraveedu PT, Ma M, Thandavarayan RA, Sukumaran V et al. Protective effect of carvedilol on daunorubicin-induced cardiotoxicity and nephrotoxicity in rats. Toxicology. 2010;274:18-26.

12. Soga M, Kamal FA, Watanabe, K, Ma, M, Palaniyandi S, Prakash $\mathrm{P}$ et al. Effects of angiotensin II receptor blocker (candesartan) in daunorubicin-induced cardiomyopathic rats. Int J Cardiol. 2005; 110:378-85.

13. Ibrahim MA, Ashour OM, Ibrahim YF, El-Bitar HI, Gomaa W, Abdel-Rahim SR. Angiotensin-converting enzyme inhibition and angiotensin AT(1)-receptor antagonism equally improve doxorubicin-induced cardiotoxicity and nephrotoxicity. Pharmacol Res. 2009;60:378-81.

14. Giri SN, Al-Bayati MA, Du X, Schelegle E, Mohr FC, Margolin SB.,. Amelioration of doxorubicin-induced cardiac and renal toxicity by pirfenidone inrats. Cancer Chemother Pharmacol. 2004;53, 141-50.

15. Nakhaoul F, Ramada R, Khankin E, Yaccob A, Kositch Z, Lewin M, Assady S, Abassi Z. Glomerular abundance of nephrin and podocin in experimental nephritic syndrome: different effects of antiproteinuric therapies. Am J Physiol Renal Physiol. 2005;289:F880-90.

16. Watanabe K, OhtaY, Nakazawa M, Higuchi H, Hasegawa G, Naito M. et al . Low dose carvedilol inhibits progression of heart failure in rats with dilated cardiomyopathy. $\mathrm{Br} \mathrm{J}$ Pharmacol. 2000;130:1489-95.

17. Yilmaz S, Atessahin A, Sahna E, Karaha I, Ozer S. Protective effect of lycopene on adriamycin-induced cardiotoxicity and nephrotoxicity. Toxicology. 2006;218;164-71.

18. Gurusamy N, Watanabe K, Ma M, Zhang S, Muslin AJ, Kodama, $\mathrm{M}$ et al. Dominant negative 14-3-3 promotes cardiomyocyte apoptosis in early stage of type I diabetes mellitus through activation of JNK. Biochem Biophys Res Commun. 2004;320:773-80. 
19. Smith PK, Krohn RI, Hermanson GT, Mallia AK, Gartner FH, Provenzano MD et al . Measurement of protein using bicinchoninic acid. Anal Biochem. 1985:150;76-85.

20. Monnier VM.. Intervention against the Maillard reaction in vivo. Arch Biochem Biophys. 2003;419:1-15.

21. Hartog JW, Voors AA, Bakker SJ, Smit AJ, van Veldhuisen DJ.,. Advanced glycation end-products (AGEs) and heart failure: pathophysiology and clinical implications. Eur J Heart Fail. 2007;9:1146-55.

22. Soni H, Pandya G, Patel P, Acharya A, Jain M, Mehta AA. Beneficial effects of carbon monoxide-releasing molecule-2 (CORM-2) on acute doxorubicin cardiotoxicity in mice: role ofoxidative stress and apoptosis. Toxicol Appl Pharmacol. 2011.15; 70-80.

23. Xin YF, Wan LL, Peng JL, Guo C. Alleviation of the acute doxorubicin-induced cardiotoxicity by Lycium barbarum polysaccharides through the suppression of oxidative stress. Food Chem Toxicol. 2011. 49; 259-64.

24. Nangaku M, Miyata T, Sada T, Mizuno M, Inagi R, Ueda Y et al. Anti-hypertensive agents inhibit in vivo the formation of advanced glycation end products and improve renal damage in a type 2 diabetic nephropathy rat model. J Am Soc Nephrol. 2003;14:1212-22.
25. Shao J, Nangaku M, Inagi R, Kato H, Miyata T, Matsusaka T et al. Receptor-independent intracellular radical scavenging activity of an angiotensin II receptor blocker. J Hypertens. 2007;25:1643-49.

26. Ceriello A, Piconi, Esposito K, Giugliano D. Telmisartan shows an equivalent effect of vitamin $\mathrm{C}$ in further improving endothelial dysfunction after glycemia normalization in type 1 diabetes. Diabetes Care. 2007;30:1694-8.

27. Matsui T, Yamagishi S, Takeuchi M, Ueda S, Fukami K, Okuda, S. Irbesartan inhibits advanced glycation end product (AGE)-induced proximal tubular cell injury in vitro by suppressing receptor for AGEs (RAGE) expression. Pharmacol Res. 2010;61:34-9.

28. Yamagishi S, Matsui T, Nakamura K, Takeuchi M, Inoue H. Telmisartan inhibits advanced glycation end products (AGEs)-elicited endothelial cell injury by suppressing AGE receptor (RAGE) expression via peroxisome proliferatoractivated receptor-gamma activation. Protein Pept. Lett. 2008;15: 850-83.

29. Yamagishi S, Matsui T, Nakamura K, Inoue H, Takeuchi $\mathrm{M}$, Ueda $\mathrm{S}$ et al Olmesartan blocks advanced glycation end products (AGEs)-induced angiogenesis in vitro by suppressing receptor for AGEs (RAGE) expression. Microvasc Res. 2008;75:130-4. 